\title{
Serotypes, virulence genes profiles and antimicrobial resistance patterns of Escherichia coli recovered from feces of healthy lambs in Mexico
}

\author{
Edgar Enriquez-Gómez ${ }^{\mathrm{a}}$, Martín Talavera-Rojas ${ }^{\mathrm{a}}$, Edgardo Soriano-Vargas ${ }^{\mathrm{a}}$, \\ Armando Navarro-Ocaña ${ }^{\mathrm{b}}$, Vicente Vega-Sánchez ${ }^{\mathrm{c}}$, Saúl Aguilar-Montes de Oca ${ }^{\mathrm{a}}$, \\ Jorge Acosta-Dibarrat ${ }^{\mathrm{a}, *}$ \\ a Centro de Investigación y Estudios Avanzados en Salud Animal. Facultad de Medicina Veterinaria y Zootecnia. Universidad Autónoma del Estado de México. Toluca, \\ Estado de Mexico, Mexico \\ ${ }^{\mathrm{b}}$ Department of Public Health, Faculty of Medicine, Universidad Nacional Autónoma de México. Universidad Nacional Autónoma de México, CDMX, Mexico \\ c Área Académica de Medicina Veterinaria y Zootecnia, Instituto de Ciencias Agropecuarias (ICAP), Universidad Autónoma del Estado de Hidalgo. Tulancingo, Estado de \\ Hidalgo, Mexico
}

\section{A R T I C L E I N F O}

\section{Keywords:}

STEC

Healthy lambs

Serotypes

Escherichia coli

\begin{abstract}
A B S T R A C T
Healthy lambs are one of the major reservoirs of Shiga toxin-producing Escherichia coli (STEC) and it is known as the cause of foodborne diseases (FBD). The work objective is to characterize (STEC) isolates obtained from rectal swabs of healthy lambs herds, a total of 183 samples were obtained from sheep production units of the State of Mexico. E. coli isolates were confirmed through the amplification of the uid $A$ gene. antimicrobial sensitivity pattern was determined through Kirby-Bauer (CLSI, 2012) test and the presence $s t x_{1}$, stx $x_{2}$ and eae genes from isolates by multiplex PCR. Serotyping was performed using specific anti-O and anti-H sera (SERUNAM, Mexico) for 185 Somatic and 56 flagellar antigens. 126 isolates biochemically and molecularly identified as E. coli were obtained, of which 80 did not express any virulence factor and 46 expressed at least some (STEC) virulence factor. The highest percentage of $E$. coli resistance was for tetracycline $48.7 \%$ (39/80), followed by nalidixic acid $13.7 \%(11 / 80)$, gentamicin 6.2\% (5/80) and Ciprofloxacin 3.7\% (3/80). Resistance to amikacin, cefotaxime and ceftazidime were not detected. A frequency of 46 STEC isolates (36.2\%) were obtained, of which 28/46 (22.0\%) expressed $s t x_{1}, s t x_{2} 3 / 46(6.5 \%), s t x_{1}, s t x_{2} 13 / 46(10.2 \%)$ and eae 2/46 (1.6\%). Thirty different serotypes were obtained. The three serotypes with the highest number of isolates (four each) were: O76:H19, O118:H27 and O146:H21 which have been identified as a cause of diarrhea in human population. An isolate of serogroup O104 was obtained, with a significant importance for European public health. In virtue of the discovered serotypes and the virulence factors distribution, we can affirm that the obtained isolates from lambs in the State of Mexico are classifiable as atypical STEC of low virulence.
\end{abstract}

\section{Introduction}

STEC strains are normal inhabitants of the ruminant gastrointestinal tract (bovine, sheep and goats) (Nataro and Kaper, 1998) and are the cause of foodborne diseases (FBDs) of animal and vegetable origin (Blanco et al., 2003; Caprioli et al., 2005).

E.coli $\mathrm{O} 157: \mathrm{H7}$ has been reported in lambs and sheep; both isolated from stool, sheep meat products and byproducts (Kumar et al., 2012; Momtaz et al., 2012), on the other hand serotypes Non-O157, as OR26, O111, O103, O121, 045 and 0145 have been found in calves and sheep and identified as potential public health risk factors (Evans et al., 2008; Bai et al., 2012). The most common pathotypes causing diarrhea in sheep in Mexico as EPEC (Enteropathogenic E. coli) and ETEC (Enter- otoxigenic E.coli). (Méndez et al., 2013; Rangel-Vargas et al., 2015).

The phenomenon of antibiotic resistance in commensal and pathogenic bacteria has become a serious problem in public health (Saei et al., 2010), bacteriás development and persistence is a topic of global concern since these microorganisms are considered as a resistance genes reservoir, capable of transferring resistance genes to their offspring, and other organisms that cause foodborne diseases and zoonotic diseases (Zhang et al., 2002).

STEC strains can cause severe diseases in the human population as the Hemolytic-Uremic Syndrome (HUS) and Hemorrhagic Colitis (HC) (Paton and Paton, 1998a). The shiga toxins 1 and 2 and its variants are the main virulence factors of this microorganism. In addition to toxins, STEC denominated strains possess other pathogenicity mechanisms that

\footnotetext{
* Corresponding author.

E-mail address: jpacosta00@hotmail.com (J. Acosta-Dibarrat).
} 
allow the phenomena of attaching and effacing (A/E) as the eae chromosomal gene that encodes the outer membrane protein (OMP) of $94 \mathrm{kDa}$, called intimin (Paton and Paton 1998b).

Various investigations have revealed the existence of variants for both shiga toxins; the $s t x_{1}$ gene has 3 subtypes ( $s t x_{1 a}, s t x_{1 c}$ and $\left.s t x_{1 d}\right)$ (Zhang et al., 2002; Burk et al., 2003) and numerous $\mathbf{s t x}_{2}$ gene variants have been described $\left(s t x_{2 a}, s t x_{2 b}, s t x_{2 c}, s t x_{2 d}, s t x_{2 e}, s t x_{2 f}\right.$, and $\left.s t x_{2 g}\right)$ letting the $s t x_{2 a}, s t x_{2 c}$ and $s t x_{2 d}$ variants the most linked to the presentation of HUS (Piérard et al., 1998; Schmidt et al., 2000). Also exists a specific plasmid, which encodes hemolysin (ehxA) production that can contribute to the virulence of this type of microorganisms for the human population (Beutin et al., 1995; Schetuz and Strockbine, 2005).

The STEC serotype O157:H7 is commonly associated with the presence of HUS and HC in the human population, not solely more than 100 different serotypes associated with these suffering afflictions have been recognized (Nguyen and Sperandio, 2012). Its noteworthy mentioning, the STEC Non-O157 report which do not cause SHU and HC in Europe, Australia and Asia attributed to different serotypes as O5:NM (immobile), O6:H11, O26:NM, O48:H21, O91:NM, O111:NM, O113:H21, O128:H2 and O128:NM. Two of these serotypes (O11:NM and $\mathrm{O} 26: \mathrm{H} 11$ ) may also cause diarrhea to weaned calves (Goldwater and Bettelheim, 1995; Russmann et al., 1995; Achenson and Keusch, 1996).

In Mexico, few studies have been conducted to determine the presence of STEC strains and their virulence factors in cattle carcass, sheep and feces of domestic animals. Amézquita-López et al. (2014) found $12.5 \%$ prevalence of STEC, $5.4 \%$ of isolates were 0157 and $7.1 \%$ of isolates were No-O157, in feces of healthy domestic animals (cattle, sheep, pigs and poultry) of small rural farms in the valley of Culiacan northwestern Mexico. Cuenca-Verde et al. (2013) found 26\% prevalence of STEC No-O157 in feces of healthy sheep in one technified farm in Jalisco, Mexico. Callaway et al. (2004) found 3.3\% prevalence of STEC 0157:H7 isolated from pigs in the center of Mexico and NarvaezBravo et al. (2013) reported $23.2 \%$ prevalence of STEC O157:H7 isolated from feces of cattle and bovine animal carcasses in slaughterhouses. The objective of this research is to characterize STEC isolates and its frequency in healthy lambs in the State of Mexico.

\section{Materials and methods}

\section{Sampling and bacteriological isolation}

Sample size was estimated using the formula for finite populations (Wayne, 1991) with 20\% E. coli prevalence (Mora et al., 2005). 183 rectal swabs samples were collected from healthy lambs without diarrhea of 1-6 months age during the months of February to May 2014, from eight sheep production units located in six municipalities of the State of Mexico by convenience sampling. Samples were transferred to the Center for Investigation and Advanced Studies in Animal Health of the Autonomous University of the State of Mexico (CIESA-UAEMex).

Samples were inoculated in agar Mc-Conkey (SMAC, Beckton Dickinson, USA). After $24 \mathrm{~h}$ of incubation at $37^{\circ} \mathrm{C}$, pink colored colonies were plated on eosin-methylene blue agar (EMB) (SMAC, Beckton Dickinson, USA) to observe the metallic luster characteristic, Finally the following biochemical tests by manitol fermentation test, TSI, LIA, MIO, H2S, indole production and presence of urease and lysine decarboxylase. Furthermore, sorbitol fermentation was tested (Fig. 1).

\subsection{Genotypic identification}

To corroborate isolates identity, genotypic identification through uid A gene amplification is proceeded in principle to extract the isolates' bacterial DNA, for which isolates were inoculated in $3 \mathrm{ml}$ of BHI broth (HiMedia, USA) that were and incubated at $37^{\circ} \mathrm{C}$ for $18 \mathrm{~h}$. With a micropipette, $1.0 \mathrm{ml}$ of culture was taken and deposited in a $1.5 \mathrm{~mL}$ vial subsequently centrifuged for $5 \mathrm{~min}$ at $9279 \mathrm{~g}$ (Eppendorf Centrifuge 5415D., USA), supernatant was discarded and $400 \mu \mathrm{l}$ of distilled water were added to pellet, then vortexed during $30 \mathrm{~s}$ (Scientific Industries Inc. USA), then centrifuged for $5 \mathrm{~min}$. at $9279 \mathrm{~g}$, supernatant was discarded and $100 \mu \mathrm{l}$ of distilled water was added, then boiled $\left(95^{\circ} \mathrm{C}-100{ }^{\circ} \mathrm{C}\right)$ during $15 \mathrm{~min}$ finally was slightly centrifuged and supernatant removed to be stored at $-20^{\circ} \mathrm{C}$ (Reyes-Rodríguez et al., 2015) until its use. For uid $A$ gene amplification the following primers UAL1939 B 5' ATGGAATTTCGCCGATTTTGC $3^{\prime}$ and UAL 2105 B 5'ATTGTTTGCCTCCCTGCTGC $3^{\prime}$ were used, with an amplification product of 187 bp previously designed and evaluated by Heijnen and Medema (2006).

\subsection{Antimicrobial susceptibility test}

The antimicrobial susceptibility was assessed through a disk diffusion test standardized by the National Committee for Clinical Laboratory Standards (NCCLS). E. coli ATCC 25922 strain was used as control bacterial inoculum of each isolate was prepared in test tubes with Mueller Hinton broth medium (MH) (SMAC, Beckton Dickinson, USA). With turbidity pattern of 0.5 at McFarland scale which approximately equivalent to $1-2 \times 10^{8}$ colony forming units (CFU). Ceftriaxone $(30 \mu \mathrm{g})$, ceftazidime $(30 \mu \mathrm{g})$, Tetracycline $(30 \mu \mathrm{g})$, nalidixic acid $(30 \mu \mathrm{g})$, ciprofloxacin $(5 \mu \mathrm{g})$, amikacin $(10 \mu \mathrm{g})$ and gentamicin $(10 \mu \mathrm{g})$ disks were used in susceptibility test $\left(\mathrm{BBL}^{\mathrm{TM}}\right.$ Sensi-Disc ${ }^{\mathrm{TM}}$ Becton Dickinson. USA).

\subsection{Virulence factors}

The 126 isolates that amplified uid $A$ gene were analyzed by multiplex PCR, for the presence of $s t x_{1}, s t x_{2}$ and eae. Using the primers and conditions described by (Blanco et al., 2003) (Table 1). PCR products were visualized by electrophoresis in $2 \%$ agarose gel stained with ethidium bromide.

\subsection{Serotyping}

46 E.coli isolates were serotyped through the expression of some virulence factor and carried out according to the procedure described by Orskov and Orskov (1984). The O antisera were produced in the reference laboratory for enteric pathogens in Mexico (SERUNAM, Mexico) for 185 Somatic, and the $\mathrm{H}$ antisera for 56 flagellar antigens, and were obtained from the Statens Serum Institut (Copenhagen, Denmark).

\section{ERIC PCR}

The amplification of bacterial DNA was performed in a final volume of $50 \mu \mathrm{l}$ containing $10 \mu \mathrm{l}$ buffer, $6.0 \mu \mathrm{l} \mathrm{Mg} \mathrm{Cl} 2,1.0 \mu \mathrm{l}$ dNTPs, (dNTP Mix, Promega ${ }^{\circ}$ USA U151A) $(200 \mu \mathrm{M}$ of each dNTP) $1.0 \mu$ l ERIC 1 (IDT ${ }^{\circ}$. USA Mfg. D 173852411), $1.0 \mu$ ERIC 2 (IDT ${ }^{\oplus}$. USA Mfg. D 173852410), $0.5 \mu \mathrm{l}$ Taq Polymerase, $27.5 \mu \mathrm{l}$ free nuclease water and 3.0 $\mu$ l DNA of each sample. The PCR tests were carried out Termo BIORad T100 Thermal Cycler. USA, under the following conditions: initial denaturation of $5 \mathrm{~min}$ at $94^{\circ} \mathrm{C}$, followed by 35 cycles of $1 \mathrm{~min}$ at $94^{\circ} \mathrm{C}$ (denaturation), $1 \mathrm{~min}$ at $52{ }^{\circ} \mathrm{C}$ (alignment) and $1 \mathrm{~min}$ at $74^{\circ} \mathrm{C}$ (elongation) and final extension of $6 \mathrm{~min}$ at $74^{\circ} \mathrm{C}$ (Soler et al., 2003).

ERIC-PCR product were displayed using $7 \mu$ reaction product added to $3 \mu \mathrm{l}$ loading buffer (Blue Orange 6X Loading Type PROMEGA. USA). Electrophoresis was conducted through 1.5\% agarose gel in TBE Buffer ( $89 \mathrm{mM}$ Tris, $89 \mathrm{mM}$ boric acid y $2.5 \mathrm{mM}$ EDTA) and ran for $60 \mathrm{~min}$ at $74 \mathrm{~V}$. Gels were stained with ethidium bromide $(0.05 \mathrm{mg} / \mathrm{L})$ and was placed in an ultraviolet transilluminator (Mini BIS Pro Biol-Imaging Sytem Uv. USA) for their observation. 


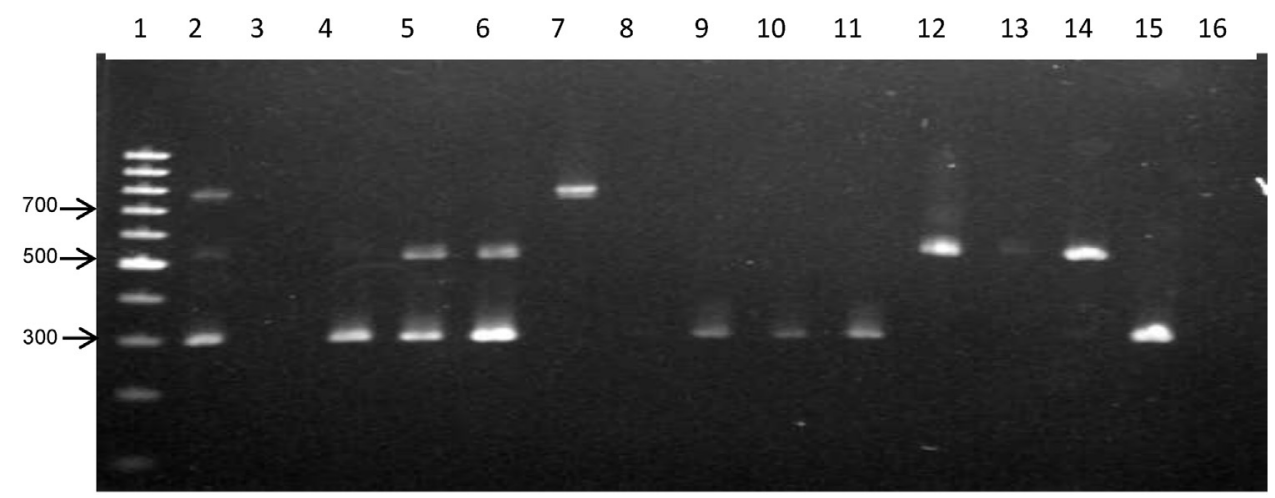

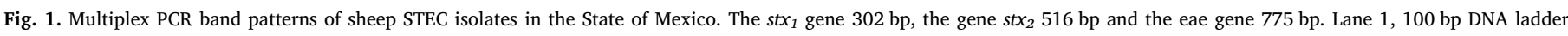

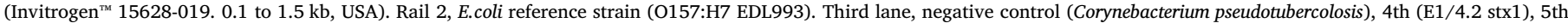

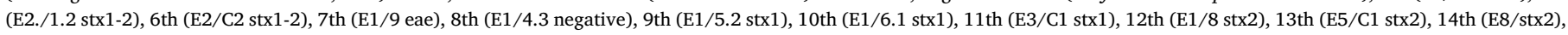
15th (E2/6.1Stx1) and 16th (E7/C18 negative).

Table 1

Primers used for multiplex PCR.

\begin{tabular}{|c|c|c|c|c|}
\hline Gene & Primer & Oligonucleotide Sequences & $\begin{array}{l}\text { Fragment } \\
\text { size (bp) }\end{array}$ & Refrence \\
\hline \multirow[t]{2}{*}{$s t x_{1}$} & VT1-A & CGCTAATGTCATTCGCTCTGC & \multirow[t]{2}{*}{302} & \multirow{2}{*}{$\begin{array}{l}\text { Blanco } \\
\text { et al. } \\
(2003)\end{array}$} \\
\hline & VT1-B & CGTGGTATAGCTACTGTCACC & & \\
\hline \multirow[t]{2}{*}{$s t x_{2}$} & VT2-A & CTTCGGTATCCTATTCCCGG & \multirow[t]{2}{*}{516} & \multirow{2}{*}{$\begin{array}{l}\text { Blanco } \\
\text { et al. } \\
(2003)\end{array}$} \\
\hline & VT2-B & CTGCTGTGACAGTGACAAAACGC & & \\
\hline \multirow[t]{2}{*}{ eae } & EAE-1 & GAGAATGAAATAGAAGTCGT & \multirow[t]{2}{*}{775} & \multirow{2}{*}{$\begin{array}{l}\text { Blanco } \\
\text { et al. } \\
(2003)\end{array}$} \\
\hline & EAE-2 & GCGGTATCTTTCGCGTAATCGCC & & \\
\hline
\end{tabular}

Statistical analysis

A variance analysis was established for antibiotics resistance results between STEC and non STEC isolates. The virulence factors results were analyzed by descriptive statistics sorting data in tables.

\section{Results}

Regarding a total of 183 samples of the obtained rectal swabs, 126 isolates were confirmed by the amplification of the uid A gene, which determines an $E$. coli isolate frequency of $68.8 \%$. (Table 2). Of 126 isolates, 46 expressed at least one of the studied virulence factors and were serotyped, while 80 did not express any of the studied virulence factors both isolates that expressed some or any virulence factor were subjected to in vitro sensitivity test ( $\mathrm{p}>0.05$ ). (Table 3 ).

Concerning E. coli antimicrobial resistance, the greatest resistance percentage was observed for tetracycline (TE) with 48.7\% (39/80) followed by the nalidixic acid (NA) with $13.7 \%$ (11/80), gentamicin (GE) $6.2 \%$ (5/80), ciprofloxacin (CIP) 3.7\% (3/80). Amikacin ceftriaxone and ceftazidime did not present any resistance.

Table 2

E.coli isolates no.

\begin{tabular}{lllll}
\hline UPP & Municipal & Sample No. & E.coli BQ & uidA \\
\hline 1 & Xalatlaco & 20 & $19 / 95 \%$ & $16 / 80 \%$ \\
2 & Ocoyoacac & 22 & $20 / 90.9 \%$ & $20 / 90.9 \%$ \\
3 & Calimaya & 20 & $15 / 75 \%$ & $13 / 65 \%$ \\
4 & Metepec & 16 & $15 / 93.7 \%$ & $15 / 93.7 \%$ \\
5 & Temoaya & 25 & $16 / 64 \%$ & $16 / 64 \%$ \\
6 & Texcalyacac & 21 & $7 / 33.3 \%$ & $7 / 33.3 \%$ \\
7 & Jiquipilco & 36 & $27 / 75 \%$ & $27 / 75 \%$ \\
8 & Ocoyoacac & 23 & $12 / 53.1 \%$ & $12 / 53.1 \%$ \\
& & 183 & $131 / 71.5 \%$ & $126 / 68.8 \%$ \\
\hline
\end{tabular}

Table 3

E.coli isolates antibiotic resistance without any virulence factor expression and STEC isolates.

\begin{tabular}{llllll}
\hline & $\begin{array}{l}\text { E.coli isolates resistance without } \\
\text { any virulence factor expression }\end{array}$ & & $\begin{array}{l}\text { STEC isolates } \\
\text { resistance }\end{array}$ & \\
\cline { 2 - 5 } Antibiotic & No. & $\%$ & No. & $\%$ \\
\hline TE & $39 / 80$ & 48.7 & $12 / 17$ & 70.7 \\
NA & $11 / 80$ & 13.7 & $8 / 17$ & 47 \\
GE & $5 / 80$ & 6.2 & $2 / 17$ & 11.7 \\
CIP & $3 / 80$ & 3.7 & $0 / 17$ & 0 \\
AM & $0 / 80$ & 0 & $2 / 17$ & 11.7 \\
CAZ & $0 / 80$ & 0 & $0 / 17$ & 0 \\
CTX & $0 / 80$ & 0 & $0 / 17$ & 0 \\
\hline
\end{tabular}

$\mathrm{P}>0.05$ (No significant differences).

In 17/46 STEC isolates that expressed phenotypic resistance, tetracycline was the antibiotic with the largest number of resistant strains with $70.7 \%(12 / 17)$, nalidixic acid $47.7 \%$ (8/17), gentamicin $11.7 \%$ (2/17), amikacin $11.7 \%$ (2/17), ciprofloxacin, ceftazidime and cefotaxime did not presented any resistance (Table 3). It was observed that 6 STEC isolates with different serotypes and virulence genes expression profile, expressed phenotypic resistance to more than one antibiotic (Table 4).

46 isolates expressed some virulence genes $36.5 \%(126 / 46)$, of which: 28 (22.2\%) expressed $s t x_{1}, 3$ expressed $s t x_{2}$ (2.3\%), 13 expressed both $s t x_{1}$ and $s t x_{2}(10.3 \%)$ and two isolates expressed eae $(1.5 \%)$ (Table 4).

STEC isolates belonged to 19 different serogroups $\mathrm{O}$ and 30 different serotypes O:H. $68 \%$ of the isolates belonged to one of the following five serogroups: O8, O76, O118,O146, O153, O176, 0185 and O187, 39.1\% of the isolates belonged to the following serotypes: O76:H19, O118:H27, O146:H21, O176:NM and O187:H28. (Table 4)

Forty percent of the isolates belonged to O79:H19, O118:H27 and O146:H21 serotypes (4 isolates/serotype). The $20 \%$ of the isolates belonged to O176:NM and O187:H21 serotypes(3 isolates/serotype) (Table 4).

Its noteworthy mentioning the presence of $0104: \mathrm{H} 7, \mathrm{O} 146: \mathrm{H} 21$, O76:H19, and ONT:H21 serotypes causing diarrhea in humans. (Table 4)

ERIC-PCR was realized to evaluate the clonal relationship between E. coli isolates that expressed some virulence factor, 44/46 STEC isolates showed a $95.6 \%$ of genetic diversity. Only two isolates obtained from male lambs, of the same production unit were sensitive to all used antibiotics and showed the same bands pattern through the expression of $s t x_{1}$ gene, which could mean a same clonal profile. Only varied in serotype expression, one expressed 0176:H19 serotype and the other 
Table 4

STEC isolates serotypes and virulence factors of isolates obtained from healthy sheep feces.

\begin{tabular}{|c|c|c|c|c|c|c|c|}
\hline \multirow[b]{2}{*}{ Serotype } & \multirow[b]{2}{*}{ Isolates } & \multirow[b]{2}{*}{ isolates No } & \multirow[b]{2}{*}{$\begin{array}{l}\text { Resistance } \\
\text { profile }\end{array}$} & \multirow[b]{2}{*}{$s t x_{1}$} & \multicolumn{2}{|c|}{$\begin{array}{l}\text { Virulence } \\
\text { factores. }\end{array}$} & \multirow[b]{2}{*}{ eae } \\
\hline & & & & & $s t x_{2}$ & $\begin{array}{l}s_{1} x_{1} \\
\text { and }{ }_{2}\end{array}$ & \\
\hline O2:NM & E8 C13 & 1 & NA, TE & & $\mathrm{X}$ & & \\
\hline O8:H9 & E5 C1 & 1 & S & & $\mathrm{X}$ & & \\
\hline O8:H20 & E1 4.2 & 1 & GM,TE & $\mathrm{X}$ & & & \\
\hline O8:H49 & E2 5.1 & 1 & S & $\mathrm{X}$ & & & \\
\hline O17:H18 & E1 2.1 & 1 & S & & & $\mathrm{X}$ & \\
\hline O43:H2 & E7 C18 & 1 & NA,GM,TE & $\mathrm{X}$ & & & \\
\hline O55:H19 & E7 C17 & 1 & $\mathrm{TE}$ & $\mathrm{X}$ & & & \\
\hline O65:H38 & E1 3.1 & 1 & NA,TE & & & $\mathrm{X}$ & \\
\hline O76:H19 & E2 9.2 & 4 & $\mathrm{~s}$ & $\mathrm{X}$ & & & \\
\hline O76:H19 & E7 C19 & & S & $\mathrm{X}$ & & & \\
\hline O76:H19 & E3 M3 & & $S$ & $\mathrm{X}$ & & & \\
\hline O76:H19 & E3 M7 & & $\mathrm{S}$ & $\mathrm{X}$ & & & \\
\hline O76:NM & E2 4.2 & 2 & S & $\mathrm{X}$ & & & \\
\hline O76:NM & E7 C1 & & S & $\mathrm{X}$ & & & \\
\hline O104:H7 & E5 C10 & 1 & NA,TE & $\mathrm{X}$ & & & \\
\hline O118:H27 & E1 5.1 & 4 & $S$ & $\mathrm{X}$ & & & \\
\hline O118:H27 & E1 9 & & $S$ & & & & $\mathrm{X}$ \\
\hline O118:H27 & E2 2.2 & & S & & & $\mathrm{X}$ & \\
\hline O118:H27 & E1 8 & & $\mathrm{~S}$ & & $\mathrm{X}$ & & \\
\hline O118:H41 & E1 6.1 & 1 & $S$ & $\mathrm{X}$ & & & \\
\hline O128 AC:NM & E5 C11 & 1 & S & & & $\mathrm{X}$ & \\
\hline O139:NM & E3 C5 & 1 & $\mathrm{AM}$ & $\mathrm{X}$ & & & \\
\hline O146:H21 & E2 5.2 & 4 & S & & & $\mathrm{X}$ & \\
\hline O146:H21 & E4 C13 & & S & & & $\mathrm{X}$ & \\
\hline O146:H21 & E2 4.1 & & NA & & & $\mathrm{X}$ & \\
\hline O146:H21 & E2 1.2 & & NA & & & $\mathrm{X}$ & \\
\hline O153:H21 & E3 C10 & 2 & $\mathrm{AM}$ & $\mathrm{X}$ & & & \\
\hline O153:H21 & E3 M6 & & S & $\mathrm{X}$ & & & \\
\hline O154:H21 & E2 6.2 & 1 & $\mathrm{TE}$ & $\mathrm{X}$ & & & \\
\hline O174:H8 & E4 C19 & 1 & $\mathrm{TE}$ & & & $\mathrm{X}$ & \\
\hline O176:NM & E6 C15 & 3 & S & $\mathrm{X}$ & & & \\
\hline O176:NM & E8 C19 & & S & $\mathrm{X}$ & & & \\
\hline O176:NM & E4 C18 & & $S$ & & & $\mathrm{X}$ & \\
\hline O176:H9 & E 6 C11 & 1 & S & $\mathrm{X}$ & & & \\
\hline O176:H19 & E8 C6 & 2 & $S$ & $\mathrm{X}$ & & & \\
\hline O176:H19 & E 8 C16 & & S & $\mathrm{X}$ & & & \\
\hline O179:H8 & E2 9.1 & 1 & $\mathrm{TE}$ & & & & $\mathrm{X}$ \\
\hline O185:NM & E4 C8 & 1 & $\mathrm{TE}$ & & & $\mathrm{X}$ & \\
\hline O185:H10 & E1 5.2 & 1 & NA,TE & $\mathrm{X}$ & & & \\
\hline O185:H19 & E7 C28 & 1 & NA & $\mathrm{X}$ & & & \\
\hline O187:H28 & E3 M10 & 3 & S & & & $\mathrm{X}$ & \\
\hline O187:H28 & E4 C11 & & $S$ & & & $\mathrm{X}$ & \\
\hline O187:H28 & E3 M10 & & S & $\mathrm{X}$ & & & \\
\hline $\mathrm{H} 7$ & E3 C4 & 1 & $\mathrm{TE}$ & $\mathrm{X}$ & & & \\
\hline $\mathrm{H} 21$ & E3 C10 & 1 & S & $\mathrm{X}$ & & & \\
\hline $\mathrm{OH}$ & E3 M5 & 1 & S & $\mathrm{X}$ & & & \\
\hline
\end{tabular}

Abbreviations: Resistant to: TE: Tetracycline, GE: gentamycin, AM: Amikacin and NA: Nalidixic Acid. S: sensitive to antibiotics used: Tetracycline, Gentamicin, amikacin, nalidixic acid, ciprofloxacin, ceftazidime and ceftriaxone.

O176: $\overline{\mathrm{H}}$ serotype (Fig. 2)

\section{Discussion}

The constant monitoring of the antibiotics used in animal husbandry is relevant to determine the presence and prevalence of resistant strains that potentially can be a risk factor for human health (Schroeder et al., 2002).

With regard to the E.coli isolates antibiotics resistance, in this research we found a resistance to tetracycline of $48.7 \%$, followed by nalidixic acid $13.7 \%$, gentamicin $6.2 \%$ and finally ciprofloxacin with $3.7 \%$, amikacin, ceftazidime and ceftriaxone did not present phenotypic resistance. In Ontario province, Canada, 2012, reported $12 \%$ resistance to tetracycline and $100 \%$ sensitivity to ciprofloxacin and amikacin and nalidixic acid for $E$. coli isolates from sheep flocks (Scott et al., 2012).
Scott, relates the resistance level of tetracycline to its inappropriate use in diets and drinking water that could be a risk factor to animal and human population.

In Argentina Pantozzi et al. (2010) found in sheep E.coli isolates with a resistance of $21.0 \%$ to tetracycline, with similar reports for ceftriaxone of 5.3\%. Regarding gentamicin, amikacin, ciprofloxacin and nalidixic acid, no resistance was reported. Novotna et al. (2005) in Jordan, single strain resistant to tetracycline was reported, with a percent well below the 39 isolates reported in the present investigation under different geographic and productive conditions.

In Spain sheep E.coli isolates, a resistance of $26.3 \%$ to nalidixic acid a little higher than what reported in the present work. (Orden et al., 2000). Blanco et al. (1996) in VTEC sheep isolates (Extremadura region, Spain), where the climatic conditions are different presented resistance percentages to tetracycline $76.0 \%$ higher than what reported in our study, although it remains the antibiotic with the highest resistance percentage. Respecting gentamicin, the percent was similar to what estimated in this study, and for nalidixic acid, Blanco reported $6 \%$, a lower percent than the reported in this study.

In this research, STEC isolates were reported with phenotypic expression resistant to tetracycline $70.7 \%$, nalidixic acid $47.1 \%$, gentamicin $11.7 \%$, amikacin $11.7 \%$, regarding ciprofloxacin, ceftriaxone and ceftazidime no phenotypic resistance was reported. In addition, a phenotypic expression resistance was observable for more than one antibiotic, where four isolates expressed resistance to tetracyclinenalidixic acid, one isolate to tetracycline-gentamicin and one isolate to tetracycline-gentamicin-nalidixic acid.

A work realized in Brazil with sheep STEC isolates of Dorper race, in tropical conditions (Ferreira et al., 2015) reported a lower percent for gentamicin $4.5 \%$ and highest resistance for tetracycline antibiotic with $12.2 \%$, a percent lower than the reported in this research. Ferreira et al. (2015) were able to detect resistance to ceftazidime with a $5.6 \%$, in comparison with the present study where no cephalosporin resistance was reported, lastly, Ferreira et al. (2015) reported a 1.1\% resistance for amikacin.

In an investigation carried out in the Valley of Culiacán, Sinaloa with healthy backyard sheep Amézquita-López et al., (2016) reported STEC isolates, with resistance to amikacin, gentamicin and tetracycline, also reported isolates with serotype 0146:H21 resistant to cephalosporin, in the present work we obtained the same serotype but with resistance to nalidixic acid. It is important to mention that Amézquita-López et al. (2016) reported in Mexico resistance to more than one antibiotic cephalothin-chloramphenicol, cephalothin-Gentamicin, Ampicillin-cephalothin-tetracycline, ampicillin-cephalothinchloramphenicol-tetracycline in STEC 0157 and No-O157 isolates.

In the USA (Edrington et al., 2009) reported resistance to more than one antibiotic in 0157:H7 isolates obtained from lambs, reported two isolates resistant to two antibiotics and an insolate resistant to eight antibiotics.

In the present investigation we were able to find a $36.5 \%(46 / 126)$ of STEC isolates. The resistance percentage was similar to the one reported in India, $32 \%$ of isolates obtained from lambs under a transhumance system (Bandyopadhyay et al., 2011), in Iran 36.8\% (Tahamtman and Namavari et al., 2014), in Spain 35\% in healthy lambs (Rey et al., 2003), in Australia 31\% (Djordjevic et al., 2001) and in New Zealand $48 \%$ of STEC in lambs (Cookson et al., 2006).

There are reports of STEC slightly lower than that reported in this study, in Mexico 26\% from healthy sheeps (Cuenca-Verde et al., 2013). In India reported $24.1 \%$ of STEC presentation in lambs with and without diarrhea (Wani et al., 2009), also in India, 24\% found in lamb's samples (Kumar et al., 2012). In Iran, a research established with healthy sheep 22.4\% (Ghanbarpour and Kiani, 2013) and in China reported a STEC percent bit less of $19.8 \%$ in healthy sheep (Gu et al., 2011).

In this investigation $s t x_{1}$ gene was reported as the virulence factor with the highest presentation frequency of $22.2 \%$, followed by $s t x_{1}-s t x_{2}$ 


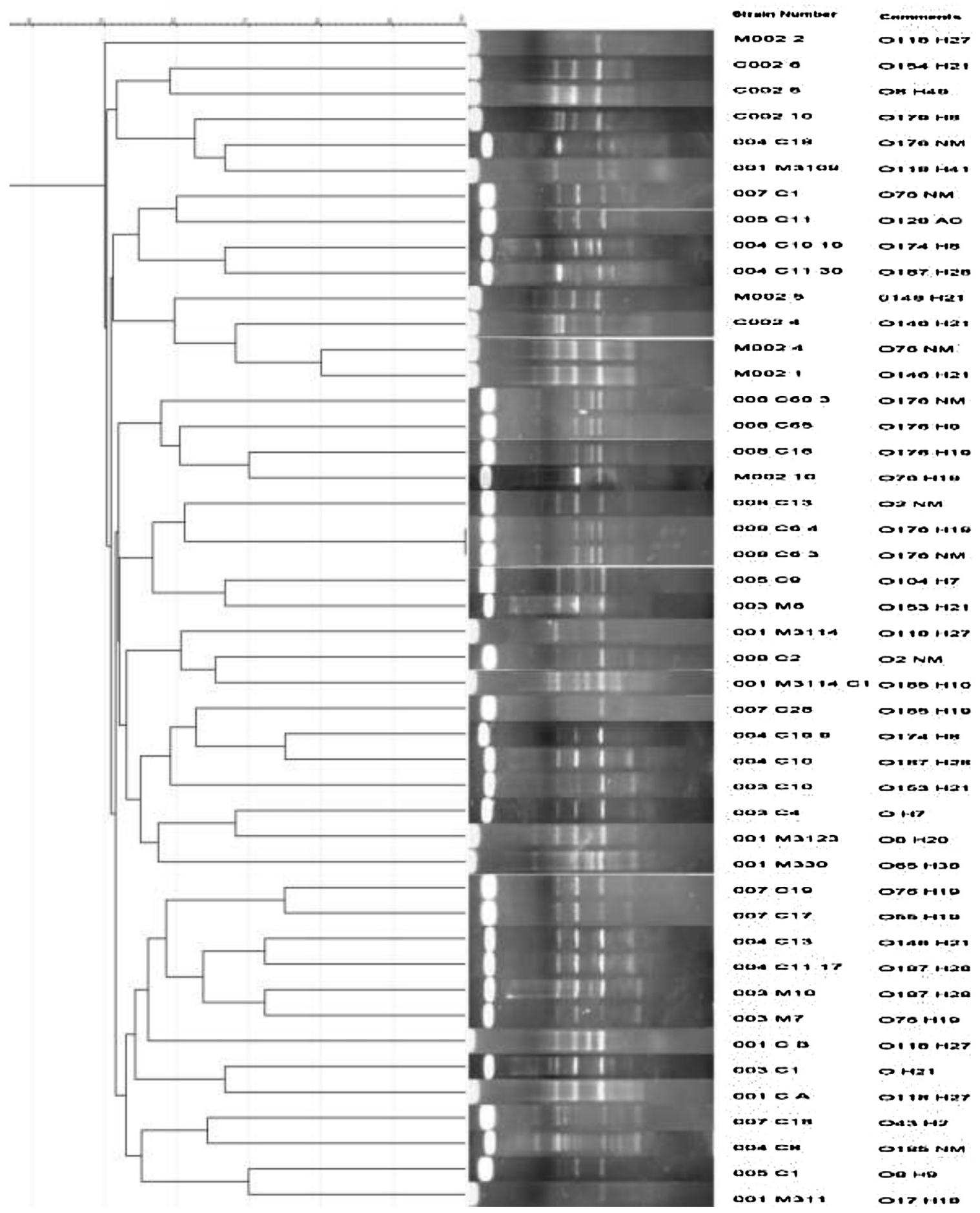

Fig. 2. ERIC-PCR bands pattern dendrogram of $46 \mathrm{E}$ coli STEC isolates. 44 presented different band patterns and two presented similar band patterns.

$10.3 \%, s t x_{2} 2.3 \%$, regarding eae gene this paper shows a frequency of $1.5 \%$. There are different investigations carried out for STEC detection around the world which is also considered as the distribution pattern of the virulence $s t x_{1}, s t x_{2}$ and eae genes, which coincide with the present study (Blanco et al., 2003; Brett et al., 2003; Zweifel et al., 2004; Wani et al., 2009; Cookson et al., 2006; Cuenca-Verde et al., 2013; Tahatman and Namavari, 2014; Ferreira et al., 2015) where $s t x_{1}$ presented the greater virulence factor percentage of all isolates followed by $s t x_{1-2}$, then $s t x_{2}$ and finally eae. In case of eae gene, this study reported similar results to those reported in Switzerland (Zweifel et al., 2001), Spain (Rey et al., 2003) and India (Bhat et al., 2008).

These data suggest that the reported isolates when not expressing the $s t x_{1}, s t x_{2}$ and eae genes together, could be named atypical STEC and thus of low virulence, however, continue representing a risk factor to public health, since isolates have been reported lacking the expression of eae gene as a cause of diarrhea in humans (Strockbine et al., 1997; Nataro and Kaper 1998; Kumar et al., 2004).

In this research, an isolate of serotype 0104:H7 with expression of $s t x_{1}$ gene was detected, belonging to 0104 serogroup. This serogroup gained more importance since it introduced a severe outbreak of hemolytic uremic syndrome in Germany in 2011 attributed to O104:H4 serotype present in products with plant origin, possibly water was contaminated with residues of ruminant's feces (Mora et al., 2011; Duffy et al., 2014). 
Another diarrhea causing STEC serotype in human population is O146:H21, in this investigation four isolates are reported with expression of $s t x_{1}$ and $s t x_{2}$ genes. Researches in other countries reported this same serotype from healthy adult sheep and lambs, in Spain (Blanco et al., 2003; Rey et al., 2003; Mora et al., 2005); Mexico (Cuenca-Verde et al., 2013 Amézquita-López et al., 2014), Brazil (Vettorato et al., 2009) and Norway (Urdahl et al., 2001) isolates from healthy adult sheep and lambs. Serotypes O104:H7 and O146:H21 along with O76:H19 serotype (with expression of $s t x_{1}$ gene) and ONT:H21 (with expression of $s t x_{1}$ gene) found in this study are responsible for cases of diarrhea in humans in Mexico; which makes these serotypes, in particular, a possible risk factor for public health (Eslava et al., 1994).

With regard to ERIC-PCR study, 44 of the 46 isolates showed different bands patterns, only two isolates showed similar bands patterns, which suggest a same clonal profile; these two isolates possess the same resistance pattern to the used antibiotics, expressing $s t x_{1}$ gene and belonged to the same serogroup, differ only in the flagellar $\mathrm{H}$ antigen expression, the isolate $008 \mathrm{C} 16$ express O176:H19 serotype, while $008 \mathrm{C} 2$ isolate express $0176: \overline{\mathrm{H}}$ serotype. This can be explained by the variation in $\mathrm{H}$ antigen expression of the phase variation phenomenon (Stainer et al., 1994), which explains that some $E$. coli isolates have two genetic determinants sets for different flagellar antigens, susceptible to alternation regarding its phenotypic expression, as bacteria multiply. Presenting with a certain probability, the variant fliC $\mathrm{H} 19$ flagellar gene is responsible for this variation, because it is responsible for proteins polymerization, forming bacterial flagellar filaments (Osek and Gallien, 2002).

\section{Conclusions}

The STEC isolates frequency was 36.5\% (46/126), no significant statistically difference was observed for antibiotics resistance among E.coli isolates and STEC. It was not able to detect isolates with the $s t x_{1}$, $s t x_{2}$ and eae genes expression simultaneously, through which STEC isolates fell into low virulence atypical STEC category. STEC isolates with serotypes that cause diarrhea in humans were detected with importance to Mexican public health, like O146:H21, O104:H7, O76:H19 and ONT:H21.

\section{Funding}

This work is part of the Master studies in Agricultural Sciences and Natural Resources of Enriquez-Gómez who received CONACyT scholarship (No. 394480) and COMECyT (No. 16BTIM0007). The research work was funded by the Autonomous University of the State of Mexico (Registration No. 3560/2013 CHT).

\section{Acknowledgements}

We appreciate the help and cooperation of the technical processes laboratory, to TQAC Luis Antonio Leon Alamilla, TA Gabriel Pérez Soto and Biol. Delia Licona Moreno of the Department of Public Health, Faculty of Medicine, Universidad Nacional Autónoma de México.

\section{References}

Achenson, D.W.K., Keusch, G.T., 1996. Which Shiga toxin-producing types of E. coli are important? ASM News 62, 302-306.

Amézquita-López, B.A., Quiñones, B., Soto-Beltrán, M., Bertram, G.L., Yambao, J.C., Lugo-Melchor, O.Y., Chaidez, C., 2016. Antimicrobial resistance profiles of Shiga toxin-producing Escherichia coli $\mathrm{O} 157$ and Non- 157 recovered from domestic farm animals in rural communities in Northwestern Mexico. Antimicrob. Resist. Infect. Control. 5 (1). http://dx.doi.org/10.1186/s13756-015-0100.

Amézquita-López, B.A., Quiñones, B., Cooley, M.B., León-Félix, J., Castro del Campo, N., Mandrell, R.E., Jiménez, M., Chaidez, C., 2014. Genotypic analyses of Shiga toxin-producing Escherichia coli $\mathrm{O} 157$ and non-O157 recovered from feces of domestic animals on rural farms in Mexico. Front. Cell. Infec.t Microbiol. 4, 7. http:// dx.doi.org/10.3389/fcimb.2014.00007.
Bai, J., Paddock, Z.D., Shi, X., Li, S., An, B., Nagaraja, T.G., 2012. Applicability of a multiplex PCR to detect the seven major shiga toxin-producing Escherichia coli based on genes that code for serogroup-specific O-antigens and major virulence factors in cattle feces. Foodborne Pathog. Dis. 9, 541-548. http://dx.doi.org/10.1089/fpd. 2011.1082.

Bandyopadhyay, S., Mahanti, A., Samanta, I., Dutta, T.K., Monoj, T., Ghosh, A., Bera, K., Bandyopadhyay, S., Bhattacharya, D., 2011. Virulence repertoire of Shiga toxinproducing Escherichia coli (STEC) and enterotoxigenic Escherichia coli (ETEC) from diarrhoeic lambs of Arunachal Pradesh, India.T rop. Anim. Health Prod. 43, 705-710. http://dx.doi.org/10.1007/s11250-010-975.

Beutin, L., Geiger, D., Zimmermann, S., Karch, H., 1995. Virulence markers of Shiga like toxin producing Escherichia coli isolates originating from healthy domestic animals of different species. J. Clin. Microbiol. 33, 631-635.

Bhat, M.A., Nishikawa, Y., Wani, S.A., 2008. Prevalence and virulence gene profiles of Shiga toxin-producing Escherichia coli and enteropathogenic Escherichia coli from diarrhoeic and healthy lambs in India. S. Rum. Res. 75, 65-70.

Blanco, M., Blanco, J., Blanco, J.E., González, E.A., Alonso, M.P., Maas, H., Jansen, W.H., 1996. Prevalence and characteristics of human and bovine verotoxigenic Escherichia coli isolates isolated in Galicia (North Westerns Spain). Eur. J. Epidemiol. 12, 13-19.

Blanco, M., Blanco, J.E., Mora, A., Rey, J., Alonso, J.M., Hermoso, M., Alonso, M.P., Dahbi, G., González, E.A., Bernárdez, M.I., Blanco, J., 2003. Serotypes virulence genes, and intimin types of Shiga toxin (verotoxin)-producing Escherichia coli isolates from healthy sheep in Spain. J. Clin. Microb. 41, 1351-1355.

Brett, K., Ramachandran, V., Hornitzky, M., Bettelheim, K.A., Walker, M.J., Djordjevic, S., 2003. stx1c Is the Most Common Shiga Toxin 1 Subtype among Shiga ToxinProducing Escherichia coli Isolates from Sheep but Not among Isolates from Cattle. J. Clin. Microbiol. 926-936. http://dx.doi.org/10.1128/jcm.41.3.926-936.2003.

Burk, C., Dietrich, R., Acar, G., Moravek, M., Bülte, M., Märtlbauer, E., 2003. Identification and characterization of a new variant of Shiga toxin 1 in Escherichia coli ONT:H19 of bovine origin. J. Clin. Microbiol. 41, 2106-2112.

CLSI (Clinical and Laboratory Estándar Institute). 2012. Performance Standars for Antimicrobial Suceptibilty, 22nd informational supplement. M100-S22. Wayne, PA, USA, Coombes, B.K., Gilmour,M.W. and Goodman, C.D., 2011. The evolution of virulence in non-O157 Shiga toxin-producing Escherichia coli. Front. Microbial. $2,1-3$.

Callaway, T.R., Anderson, R.C., Tellez, G.Z., Rosario, C., Nava, G.M., Eslava, C., Blanco, M.A., Quiroz, M.A., Olguín, A., Herradora, M., Edrington, T.S., Genovese, K.J., Harvey, R.B., Nisbet, D.J., 2004. Prevalence of Escherichia coli 0157 in cattle and swine in central Mexico. J. Food Prot. 67, 2274-2276.

Caprioli, A., Morabito, S., Brugère, H., Oswald, E., 2005. Enterohaemorrhagic Escherichia coli: emerging issues on virulence and modes of transmission. Vet. Res. 36, 289-311.

Cookson, A.L., Taylor, S.C.S., Bennett, J., Thomson-Carter, F., Attwood, G.T., 2006. Serotypes and analysis of distribution of Shiga toxin-producing Escherichia coli from cattle and sheep in the lower North Island, New Zealand. N. Z. Vet. J. 54, 78-84. http://dx.doi.org/10.1080/00480169.2006.36616.

Cuenca-Verde, N.M., Tórtora, P.J., Eslava Campos, C., Tenorio. G.V., Diaz-Aparício, E., Alba, H.F., Cuenca-Verde, C., Valdivia, A., 2013. Aislamiento de E. coli productora de shiga-like toxin en ovinos con diarrea en un sistema de producción intensiva. Memorias del XVII congreso internacional de ovinocultura 23 al 25 de Octubre de 2013. Acapulco.Guerrero, México . pp 282.

Djordjevic, S.P., Hornitzky, M.A., Bailey, G., Gill, P., Vanselow, B., Walker, K., 2001. Virulence properties and serotypes of Shiga toxin-producing Escherichia coli from healthy Australian slaughter-age sheep. J. Clin. Microbiol. 39, 2017-2021. http://dx. doi.org/10.1128/JCM.39.5. 2017-2021.2001.

Duffy, G., Burgess, C.M., Bolton, D.J., 2014. A review of factors that affect transmission and survival of verocytotoxigenic Escherichia coli in the European farm to fork beef chain. Meat Sci. 97, 375-383. http://dx.doi.org/10.1016/j.meatsci.2014.01.009.

Edrington, T., Long, M., Ross, T., Thomas, J., Callaway, T.R., Anderson, R.C., Craddock, F., Salisbury, M., Nisbet, D.J., 2009. Prevalence and Antimicrobial Resistance Profiles of Escherichia coli O157:H7 and Salmonella Isolated from Feedlot Lambs. J. Food Protect. 72, 1713-1717.

Eslava, C., Mateo, J., Cravioto. A., 1994. Cepas de Escherichia coli relacionadas con la diarrea. en: diagnóstico de laboratorio de infecciones gastrointestinales. Giono S, Escobar A, Valdespino JL. Secretaria de Salud. México: 251.

Evans, J., Knight, H.I., Smith, A.W., Pearce, M.C., Hall, M., Foster, G., Low, J.C., Gunn, G.J., 2008. Cefixime-tellurite rhamnose MacConkey agar for isolation of Vero cytotoxin-producing Escherichia coli serogroup O26 from Scottish cattle and sheep faeces. Lett. App. Microbiol. 47, 148-152.

Ferreira, M.R.A., Silva, T.S., Stella, A.E., Conceição, F.R., dos Reis, E.F., Moreira, C.N. 2015. Detection of virulence factors and antimicrobial resistance patterns in shiga toxin-producing Escherichia coli isolates from sheep. Pesq. Vet. Bras. 35, 775-780.

Ghanbarpour, R., Kiani, M., 2013. Characterization of non-O157 shiga toxin-producing Escherichia coli isolates from healthy fat-tailed sheep in southeastern of Iran. Trop. Anim. Health Prod. 45, 641-648. http://dx. doi.org/10.1007/s11250-012-0271-5.

Goldwater, P.N., Bettelheim, K.A., 1995. Hemolytic uremic syndrome due to Shiga-like toxin producing Escherichia coli O48:H21 in South Australia. Emerg. Infect. Dis. 1, $132-133$.

Gu, C., Xue, T., Xu, T., Gao, S., Jiao, X., Liu, X., 2011. Epidemiological investigation of Shiga toxin-producing Escherichia coli isolates originated from healthy sheepin one farm of Jiangsu Province and their pathogenicity. Wei Sheng Wu Xue Bao 51 , 676-683.

Heijnen, L., Medema, G., 2006. Quantitative detection of E. coli: E. coli $\mathrm{O} 157$ and other shiga toxin producing $E$. coli in water samples using a culture method combined with real-time PCR. J. Water Health. 4, 487-498.

Kumar, S.H., Karunasagar, I., Karunasagar, I., Teizou, T., Shima, K., Yamasaki, S., 2004 Characterization of Shiga toxin-producing Escherichia coli (STEC) isolated from 
seafood and beef. FEMS Microbiol. Lett. 233, 173-178.

Kumar, A., Taneja, N., Kumar, Y., Sharma, M., 2012. Detection of Shiga toxin variants among Shiga toxin-forming Escherichia coli isolates from animal stool, meat and human stool samples in India. J. Appl. Microbiol. 113, 1208-1216. http://dx.doi.org/ 10.1111/j.1365-2672.2012.05415.x.

Méndez, A., Maldonado, A., Riuz-Villamor, E., Luque, I., Bautista M.J., Enfermedades neonatales. Huerta, B., Sierra, E., Borge, C. http://www.asmexcriadoresdeovinos. org/empezar/neonatales.html (Consultadoabril 2013).

Momtaz, H., Farzan, R., Rahimi, E., Dehkordi, F.S., Souod, N., 2012. Molecular characterization of shiga toxin-producing Escherichia coli isolated from ruminant and donkey raw milk samples and traditional dairy products in Iran. Sci. World J. 2012, 231342. http://dx.doi.org/10.1100/2012/231342.

Mora, A.E., Blanco, J.A., Blanco, M., Pilar Alonso, M., Dhabi, G., Echeita, A., Enrique, A., González, M., Bernárdez, I., Blanco, J., 2005. Antimicrobial resistance of Shiga toxin (verotoxin)-producing Escherichia coli O157:H7 and non-O157 strains isolated from humans, cattle, sheep and food in Spain. Res. Microbiol. 156, 793-806. http://dx.doi. org/10.1016/resmic.2005.03.006.

Mora, A., Herrera, A., López, C., Dahb, G., Mamani, R., Pita, J.M., Alonso, M.P., Llovo, J., Bernárdez, M.I., Blanco, J.E., Blanco, M., Blanco, J., 2011. Characteristics of the Shiga-toxin-producing enteroaggregative Escherichia coli O104:H4 German outbreak strain and of STEC strains isolated in Spain. Int. Microbiol. 14, 121-141. http://dx. doi.org/10.2436/20.1501.01.142.

Narvaez-Bravo, C., Miller, M.F., Jackson, T., Jackson, S., Rodas- Gonzalez, A., Pond, K., Echeverry, A., Brashears, M.M., 2013. Salmonella and Escherichia coli O157:H7 prevalence in cattle and on carcasses in a vertically integrated feedlot and harvest plant in Mexico. J. Food. Prot. 76, 786-795. http://dx.doi.org/10.4315/0362-028X. JFP-12-079.

Nataro, J.P., Kaper, J.B., 1998. Diarrheagenic Escherichia coli. Clin. Microbiol. Rev. 11, 142-201.

Nguyen, Y., Sperandio, V., 2012. Enterohemorrhagic E. coli (EHEC) pathogenesis. Front. Cell Infect. Microbiol. 2, 90. http://dx.doi.org/10.3389/fcimb.2012.00090.

Novotna, R., Alexa, P., Hamrik, J., Madanata, A., Smol, J., Cizek, A., 2005. Isolation and characterization Shiga toxin-producing Escherichia coli from sheep and goats in Jordan with evidence of multiresistant serotype O157:H7. Vet. Med. Czech. 50, 111-118.

Orden, J.A., Ruiz-Santa-Quintera, J.A., García, S., Cid, D., De la Fuente, R., 2000. Quinolone resistance in Escherichia coli strains isolated from diarrhoeic lambs in Spain. Short communication. Vet. Rec. 147, 576-578.

Orskov, F., Orskov, I., 1984. Serotyping of Escherichia coli. In: Bergan, T. (Ed.), Methods in Microbiology. Academic Press Ltd, London, pp. 43-112.

Osek, J., Gallien, P., 2002. Molecular analysis of Escherichia coli 0157 strains isolated from cattle and pigs by the use of PCR and pulsed-field gel electrophoresis methods. Vet. Med. 47, 149-158.

Pantozzi, F., Moredo, F.A., Vigo, G.B.L., Giacoboni, G.I., 2010. Resistencia a los antimicrobianos en bacterias indicadoras y zoonóticas aisladas de animales domésticos en Argentina. Rev. Argent. Microbiol. 42, 49-52.

Paton, A.W., Paton, J.C., 1998a. Detection and characterization of Shiga toxigenic Escherichia coli by using multiplex PCR assays for $s t x 1$, stx2, eae, enterohemorrhagic E. coli hlyA, rfbo111, and rfb o157. J. Clin. Microbiol. 36, 598-602.

Paton, J.C., Paton, A.W., 1998b. Pathogenesis and diagnosis of Shiga toxin- producing Escherichia coli infections. Clin. Microbiol. Rev. 11, 450-479.

Piérard, D., Muyldermans, G., Moriau, L., Stevens, D., Lauwers, S., 1998. Identification of new verocytotoxin type 2 variant B-subunit genes in human and animal Escherichia coli isolates. J. Clin. Microbiol. 36, 3317-3322.

Rangel-Vargas, E., Gomez-Aldapa, C.A., Torres-Vitela, M., Villarruel-Lopez, A., GordilloMartinez, A.J., Castro-Rosas, J., 2015. Presence and Correlation of Some Enteric Indicator Bacteria, Diarrheageic Escherichia coli Pathotypes, and Salmonella Serotypes in Alfalfa Sprouts from Local Retail Markets in Pachuca, Mexico. J. Food Prot. 78 (3), 609-614. http://dx.doi.org/10.4315/0362-028X.JFP-14-229.

Rey, J., Blanco, J., Blanco, M., Mora, A., Dahbi, G., Alonso, J., Hermoso, M., Hermoso, J.,
Pilar, M., Usera, M., González, E., Bernárdez, M., Blanco, J., 2003. Serotypes: phage types and virulence genes of Shiga-producing Escherichia coli isolated from sheep in Spain. Vet. Microbiol. 94, 47-56.

Reyes-Rodríguez, N.E., Soriano-Vargas, E., Barba-León, J., Navarro, A., Talavera-Rojas, M., Sanso, A.M., Bustamante, A.V., 2015. Genetic characterization of Escherichia coli 15 isolated from cattle carcasses and feces in Mexico State. J. Food Prot. 78http://dx doi.org/10.4315/0362-028X.JFP-14-425. (E796-16 801).

Russmann, H.E., Kothe, H., Schmidt, S., Franke, D., Harmsen, A., Caprioli, C., Karch, H., 1995. Genotyping of Shiga-like toxin genes in non-O157 Escherichia coli strains associated with haemolytic uraemic syndrome. J. Med. Microbiol. 42, 404-410. http://dx.doi.org/10.1099/00222615-42-6-404.

Saei, D.H., Ahmadi, E., Kazemnia, A., Ahmadinia, M., 2010. Molecular identification and antibiotic susceptibility patterns of Escherichia coli isolates from sheep faeces samples. Comp. Clin. Pathol. 21, 467-473. http://dx.doi.org/10.1007/s00580-010-1134-y.

Schetuz, F., Strockbine, N.A., 2005. Genus Escherichia. In: Garrity, G.M., Brenner, D.J., Krieg, N:r:, Staley, J.Y. (Eds.), Bergeýs Manual of Sistematic Bacteriology. Springer, New York, NY, pp. 607-624.

Schmidt, H., Scheef, J., Morabito, S., Caprioli, A., Wieler, L.H., Karch, H., 2000. A new Shiga toxin 2 variant (Stx2f) from Escherichia coli isolated from pigeons. Appl. Environ. Microbiol. 66, 1205-1208.

Schroeder, M.C., Zhao, C., Debroy, C., Torcolini, J., Zhao, S., White, D.G., Wagner, D.D., McDermott, F.P., Walker, D.R., Meng, J., 2002. Antimicrobial Resistence of E.coli O157 Isolated from humans, cattle, Swine and food. Appl. Environ. Microbiol. 68, 576-581.

Scott, L., Menzies, P., Reid-Smith, R.J., Avery, B.P., McEwen, S.A., Moon, C.S., Berke, O., 2012. Antimicrobial resistance in fecal generic Escherichia coli and Salmonella spp. obtained from Ontario sheep flocks and associations between antimicrobial use and resistance. Can. J. Vet. Res. 76, 109-119.

Soler, L., Figueras, M.J., Chacón, M.R., Guarro, J., Martinez-Murcia, A.J., 2003. Comparison of three molecular methods for typing Aermonoa popoffi isolates. Antonie Van Leeuwenhoek 83, 341-349.

Stainer, R.Y., Ingraham, J.1., Mark, L., Wheels, Y., 1994. Microbiología, 2a ed. Editorial Reverté SA.

Strockbine, N., Sowers, E., Greene, T., Hayes, P., Griffin, P., Wells, G., 1997. Characterization of Shiga-toxin producing non-O157 Escherichia coli from the United States, 1983-1997. Abstracts of the 3rd International Symposium and Workshop on ShigaToxin (Verotoxin).

Tahatman, Y., Namavari, M., 2014. Prevalence of O157 and Non O157 in Iranian Domestic sheep. Pak. J Biol. Sci. 1, 104-108.

Urdahl, A.M., Alvseike, O., Skjerve, E., Wasteson, Y., 2001. Shiga toxin genes (stx) in Norwegian sheep herds. Epidemiol. Infect. 127, 129-134 (10.1017S0950268801005751).

Vettorato, M.P., de Castro, A.F.P., Cergole-Novella, M.C., Camargo, F.L.L., Irino, K., Guth, B.E.C., 2009. Shiga toxin-producing Escherichia coli and atypical enteropathogenic Escherichia coli strains isolated from healthy sheep of different populations in São Paulo, Brazil. Lett. Appl. Microbiol. 49, 53-59.

Wayne WWD. (1991). Bioestadística: Bases para el análisis de las ciencias de la salud. Limusa S.A de C.V. México D.F. $6^{\circ}$ Impresión.

Wani, S.A., Hussain, I., Fayaz, I., Mir, M.A., Nishikawa, Y., 2009. Subtype analysis of stx1, stx2 and eae genes in Shiga toxin-producing Escherichia coli (STEC) and typical and atypical enteropathogenic E. coli (EPEC) from lambs in India. Short Communication. Vet. J. 182, 489-490. http://dx.doi.org/10.1016/j.tvj1.2008.07.017.

Zhang, W.L., Kohler, B., Oswald, E., Beutin, L., Karch, H., Morabito, S., Caprioli, A., Suerbaum, S., Schmidt, H., 2002. Genetic diversity of intimin genes of attaching and effacing Escherichia coli strains. J. Clin. Microbiol. 40, 4486-4492. http://dx.doi.org/ 10.1128/JCM.40.12.4486-4492.2002.

Zweifel, C., Blanco, J.E., Blanco, M., Blanco, J., Stephana, R., 2004. Serotypes and virulence genes of ovine non-O157 Shigatoxin-producing Escherichia coli in Switzerland. Int. J. Food. Microbiol. 95, 19-27. http://dx.doi.org/10.1016/j. ijfoodmicro.2004.01.015. 